\title{
Experimental analysis of a novel Solar PV/T Collector
}

\author{
Jinwei Ma ${ }^{1,2}$, Weiwei Tong ${ }^{2, *}$, Tingyong Fang ${ }^{2,3}$, Wei He ${ }^{1,4}$, Kesheng Wang ${ }^{1}$ \\ ${ }^{1}$ Chinaland solar energy co.,ltd., Hefei 231600, Anhui, China \\ ${ }^{2}$ Anhui Jianzhu University, Anhui Advanced Technology Institute of Green Building, Hefei 230601, China \\ ${ }^{3}$ Key Laboratory of Intelligent Building and Building Energy Conservation, Anhui province, Hefei 230022, China \\ ${ }^{4}$ Hefei University of Technology, Hefei 230009, China
}

\begin{abstract}
The output power of the solar photovoltaic panel decreases as the operating temperature increases. The use of photovoltaic/photothermal (PV/T) collectors not only effectively cools the operating temperature of the battery, increases photovoltaic power, but also produces hot water. Therefore, the PV/T collector improves the annual utilization efficiency of solar energy, and can meet the user's demand for different energies. This paper builds an experimental platform to compare the PV/T collector photovoltaic/photothermal performance and experimental comparison with traditional PV. The results show that the PV/T collector has a thermal efficiency of $31.5 \%$ and a photovoltaic efficiency of $17.82 \%$ at a flow rate of $0.023 \mathrm{Kg} / \mathrm{s}$ to achieve high efficiency in solar energy utilization.
\end{abstract}

\section{Introduction}

The operating temperature of solar photovoltaic cells plays an important role in photovoltaic performance. It is a function of solar radiation intensity, ambient temperature, material performance parameters, and local wind speed [1]. The Meneses-Rodrigues study found that, under normal conditions, the PV efficiency of PV cells decreases with increasing operating temperature [2]. Skoplasi studied the effect of operating temperature on PV cell performance and summarized the correlation between the two [3]. As the operating temperature of the photovoltaic cell increases, the electrical efficiency and output power of the PV module decrease. Obviously, the efficiency of photovoltaic modules in low temperature environments is higher than in high temperature environments.

In order to reduce the operating temperature of the PV cell and improve the performance of the photovoltaic module. Scholars have proposed solar photovoltaic/photothermal (PV/T) collectors that combine solar cells with solar collectors to increase the efficiency of solar energy utilization at different wavelengths while generating heat and electricity. Wolf proposes a combination of PV cells and water heaters to simulate the combined system performance to take full advantage of solar radiant energy [4]. PV/T collectors are better able to utilize solar radiant energy than PV modules that convert only part of the solar radiant energy into electrical energy. Raghuraman established a one-dimensional heat transfer model for PV/T collectors and flat-plate solar collectors, and proposed a method to improve the performance of the collectors by analyzing their performance [5]. Bhattarai et al. studied the effects of different structural features on the performance of
PV/T collectors [6]. He Wei et al. conducted a comparison of optoelectronic/photothermal efficiency experiments on single-function PV photovoltaic panels and solar collectors and dual-function $\mathrm{PV} / \mathrm{T}$ collectors [7]. The results show that the photoelectric/photothermal comprehensive efficiency of the dual-function $\mathrm{PV} / \mathrm{T}$ collector is significantly higher than that of the singlefunction solar water heater and photovoltaic panel. Ji Jie et al. designed a heat transfer model, applied PV/T collectors to the building and analyzed the system's annual performance [8]. Guo Chao proposed a multifunctional solar PV/T collector, which combines the functions of heated air and heated water and conducts experimental research on $\mathrm{PV} / \mathrm{T}$ air collection and $\mathrm{PV} / \mathrm{T}$ water collection respectively [9]. The results show that the PV/T system can efficiently use solar energy in both modes.

In this paper, the experimental bench is used to analyze the photoelectric/photothermal performance of solar PV/T collectors at different flow rates, and the comparative performance experiments of internal anhydrous $\mathrm{PV} / \mathrm{T}$ and ordinary $\mathrm{PV}$ are carried out.

\section{Experimental system and equipment}

\subsection{Dual function PV/T collector structure}

The structure of the PV/T collector is shown in Figure 1. The collector includes: a glass cover, a solar cell, a heat absorbing plate, a copper branch pipe, a header, and an insulation layer. The heat absorbing plate is an aluminum plate having a height of $1.52 \mathrm{~m}$ and a width of $0.9 \mathrm{~m}$. The front side is laminated with 72 monocrystalline silicon cells in series, and the back is 7

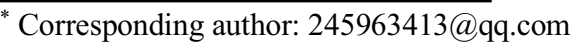


laser-welded copper branches with an inner diameter of $8 \mathrm{~mm}$. The total area of the solar cell is $1.76 \mathrm{~m}^{2}$, and the portion of the surface of the heat absorbing plate that is not covered by the battery is a black absorbing coating. The branch pipe is connected to the system waterway through the collectors at both ends of the collector. The back and side insulation layers are glass fibers having a thickness of $0.03 \mathrm{~m}$.

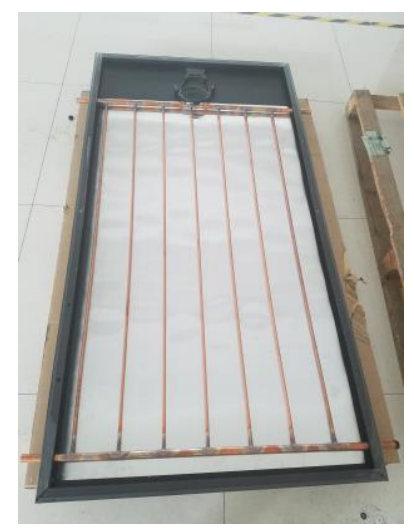

Fig. 1. Real picture of dual-function PV/T collector.

\subsection{Experimental installation of photovoltaic/wat-er thermal system}

The experimental platform of the photovoltaic/water collector system is show in Figure 3. The water system uses mechanical circulation. The collector is connected to the water tank vertically above the insulated water pipe, and the water in the water tank is $120 \mathrm{~L}$ during the experiment. In the experimental test, the vertical water tank in the tank will produce significant temperature stratification, and three temperature measuring points are uniformly distributed along the height direction of the tank axis to determine the water temperature. In the collector, three temperature measuring points are evenly arranged along the water flow direction of the central branch pipe, and one temperature measuring point is arranged in the inlet and outlet of the collector water pipe to measure the water temperature of the collector. The temperature measurement points are all copperconstantan thermocouples (accuracy grade $\pm 0.5^{\circ} \mathrm{C}$ ). The system photovoltaic circuit is connected with a controller, a load and a battery. The controller has an inverter function and power tracking, and the photovoltaic energy output is measured by a power sensor (accuracy level $0.2)$.

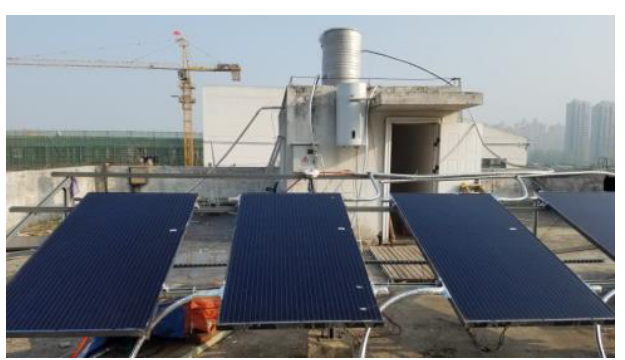

Fig.2. Dual-function PV/T collector experimental system diagram.
The photovoltaic/photothermal performance test of solar PV/T collector is carried out in Hefei outdoor, the collector orientation is positive south direction, the inclination angle is $35^{\circ}$, and the solar irradiance is model TBQ-2 solar total radiation meter. It was measured that the system water flow was measured by a turbine flowmeter (accuracy level 0.5), and the experimental measurement data were recorded by a data acquisition instrument (HIOKI LR8402) with a recording time of 1 $\min$.

\section{Experimental results and analysis}

\subsection{Solar PV/T collector performance evaluation method}

The solar PV/T collector can generate both electric and thermal energy, and its performance is evaluated by the efficiency of the converted electric and thermal energy.

The thermal efficiency of $\mathrm{PV} / \mathrm{T}$ collector is defined as the ratio of the all-day heat gain of water in the tank to the solar radiation absorbed by the collector throughout the day. which is expressed as:

$\eta_{\text {th }}=\frac{M C_{P}\left(T_{\text {final }}-T_{\text {initial }}\right)}{H A_{c}}$

$\mathrm{PV} / \mathrm{T}$ collector PV efficiency can be defined as the

ratio of solar radiation absorbed by the collector throughout the day to electricity generated by the collector throughout the day. which is expressed as:

$\eta_{t h}=\frac{\sum U I}{G A_{p v}}$

Since electrical energy is a high-grade energy compared with thermal energy, a more equitable comprehensive efficiency is adopted to evaluate the efficiency of PV/T collector, expressed as:

$\eta=\eta_{t h}+\varphi \frac{\eta_{p v}}{\eta_{p}}$

Where $\varphi=A_{p v} / A_{v}$; Where $\eta_{p}$ is the conversion factor from thermal energy to electrical energy of the thermal power plant, and its value can be taken as $38 \%$.

\subsection{Performance analysis of dual-effect solar PV IT collector}

The temperature change curve of the inlet and outlet of the water tank and the collector under the photovoltaic/water collection mode is show in fig. $3\left(Q_{w}=0.023 \mathrm{~kg} / \mathrm{s}\right)$. At the beginning of the experiment, the temperature of the water tank was $20.22^{\circ} \mathrm{C}$, which was close to the inlet and average ambient temperature of the collector. The temperature of the collector outlet and the heat absorption plate is higher than the temperature of the water tank because the water in the whole system begins to circulate 30 minutes before the test. At 12:00, the temperature difference between the inlet and outlet of the collector is the largest, and after 
14:00, the temperature of the heat absorption plate drops slightly. At 16:00, the four curves were close to each other, and the outlet temperature of the collector was lower than the inlet temperature, due to the reduction of solar radiation and incidence Angle. At the end of the experiment, the water temperature in the water tank was $37.7^{\circ} \mathrm{C}$, and the water temperature in the all-day water tank was increased by $17.48{ }^{\circ} \mathrm{C}$. The all-day water collection efficiency of the system was $31.5 \%$.

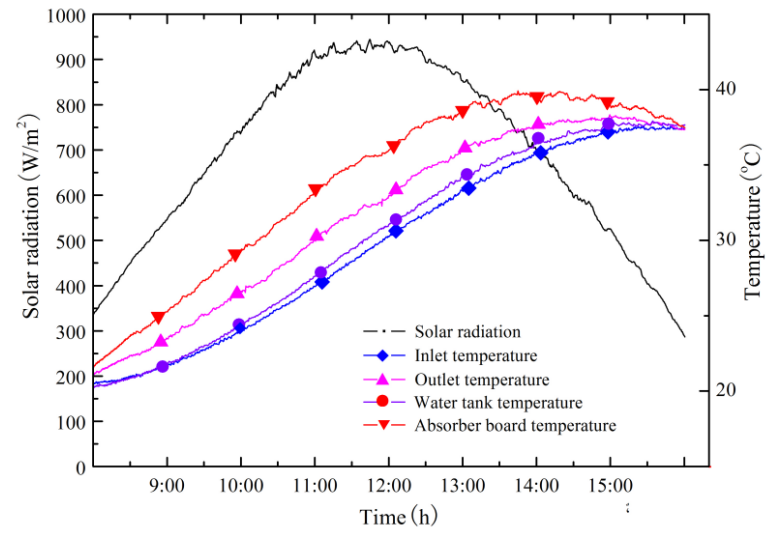

Fig. 3. Temperature changes of the inlet and outlet temperature of the collector and the temperature of the water tank in photovoltaic/water collection mode.

The electric power in photovoltaic/water collection mode is shown in fig. $4\left(Q_{w}=0.023 \mathrm{~kg} / \mathrm{s}\right)$. According to the research results of Fudholi [10] et al, the temperature of $\mathrm{PV} / \mathrm{T}$ solar battery is consistent with that of the heat sink because of the compact lamination of the heat sink and the small specific heat capacity and thickness of the solar cell. The all-day PV/T collector's electrical efficiency is higher than the contrast $\mathrm{PV} / \mathrm{T}$ collector's electrical efficiency and the ordinary PV collector's electrical efficiency, and the contrast PV/T collector's electrical efficiency is the least. At 12:00, the difference between the three is the largest. The peak power of $\mathrm{PV} / \mathrm{T}$ collector is $281.43 \mathrm{~W}$. By contrast, the peak power of $\mathrm{PV} / \mathrm{T}$ collector is $253.84 \mathrm{~W}$ and that of ordinary $\mathrm{PV}$ collector is $261.53 \mathrm{~W}$.

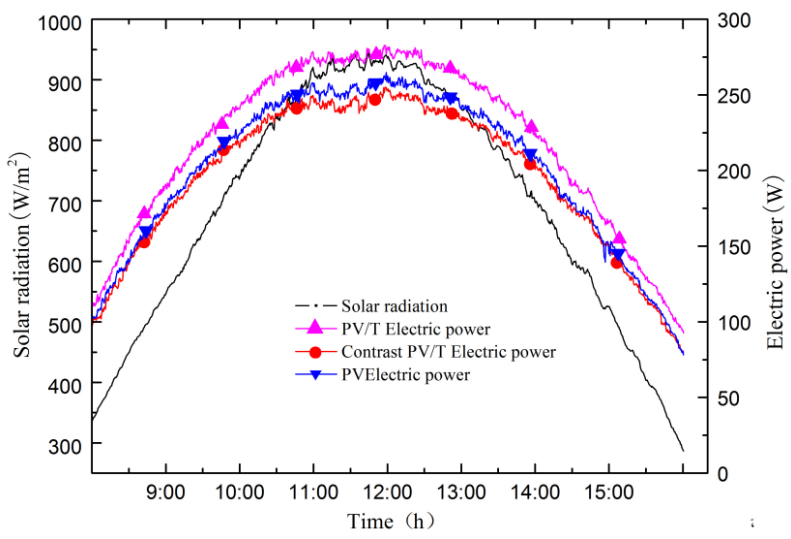

Fig.4. Change of PV/T collector and electric power in PV/ wate-r collector mode and comparison experiment.

The temperature change curve of $\mathrm{PV} / \mathrm{T}$ collector and comparison collector battery in $\mathrm{PV} /$ water collector mode is show in Fig. $5\left(Q_{w}=0.023 \mathrm{~kg} / \mathrm{s}\right)$. The variation trend of PV/T collector and contrast collector battery temperature and all-day irradiance were basically the same. The all-day comparison of PV/T collector battery temperature is higher than that of $\mathrm{PV} / \mathrm{T}$ collector and ordinary PV. The temperature changes greatly around 12:00, and the three battery temperatures reach the maximum value at 13:00.

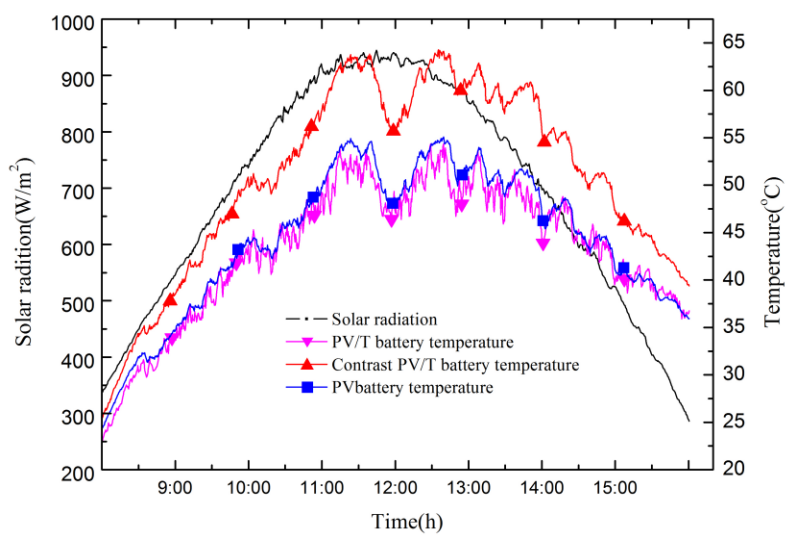

Fig. 5. PV/T collector and comparison of experimental battery temperature changes in $\mathrm{PV} /$ water collector mode

Table 1 shows the all-day photoelectric photothermal efficiency test results of PV/T collector under different water flow in October 2019 and the comparison experiment. With the continuous decrease of water flow rate, the convection and heat transfer coefficient of water and heat absorption plate increases, which makes the $\mathrm{PV} / \mathrm{T}$ water collection efficiency increase continuously, but the photoelectric efficiency decreases continuously. Compared with $\mathrm{PV} / \mathrm{T}$ collector, there is no water flow and the battery temperature is high, so the photoelectric efficiency is the lowest.

Table $1 \mathrm{PV} / \mathrm{T}$ collector and photoelectric/photothermal efficiency of the comparison experiment under PV/ water heat collection mode.

\begin{tabular}{cccccc}
\hline $\begin{array}{c}Q_{w} \\
(\mathrm{~kg} / \mathrm{s})\end{array}$ & $\begin{array}{c}G \\
(\mathrm{MJ})\end{array}$ & $\begin{array}{c}\eta_{t h} \\
(\%)\end{array}$ & $\begin{array}{c}\eta_{p v / t} \\
(\%)\end{array}$ & $\begin{array}{c}\eta_{p v / t c} \\
(\%)\end{array}$ & $\begin{array}{c}\eta_{p v} \\
(\%)\end{array}$ \\
\hline 0.023 & 22.20 & 31.50 & 17.82 & 15.98 & 16.48 \\
0.033 & 18.73 & 27.79 & 18.09 & 16.32 & 16.82 \\
0.056 & 20.20 & 23.22 & 18.61 & 16.96 & 17.39 \\
\hline
\end{tabular}

\section{Conclusion}

Under the same environmental conditions, the $\mathrm{PV} / \mathrm{T}$ collector photoelectric efficiency is higher than that of the comparative $\mathrm{PV} / \mathrm{T}$ collector and ordinary PV. When the water flow rate is $0.023 \mathrm{~kg} / \mathrm{s}$, the photoelectric efficiency difference of the three is the largest. The photoelectric efficiency of the PV/T collector is $11.51 \%$ higher than that of the comparative PV/T collector, and $8.13 \%$ higher than that of the ordinary PV. This shows that increasing water heat collection is beneficial to increase PV photovoltaic efficiency.

$\mathrm{PV} / \mathrm{T}$ collector photovoltaic/water collection mode, when the water flow is $0.023 \mathrm{~kg} / \mathrm{s}$, the solar energy utilization efficiency is $75.57 \%$. This is higher than Ji Jie [11] and others in the L-shaped rib double-effect 
collector experiment with a hot water collection efficiency of $63.8 \%$. The dual-function PV/T collector has a higher solar energy utilization efficiency than a single collector solar collector, and at the same time can output electric energy and heat energy, extending the application range of the solar collector.

\section{Nomenclature}

$\mathrm{A}_{\mathrm{c}} \quad$ Collector lighting area, $\mathrm{m}^{2}$

$\mathrm{A}_{\mathrm{pv}} \quad$ Total photovoltaic cell area, $\mathrm{m}^{2}$

$\mathrm{C}_{\mathrm{p}} \quad$ Specific heat capacity of water at constant pressure, $\mathrm{J} /(\mathrm{kg} . \mathrm{K})$

$G \quad$ Total solar radiation throughout the day, $\mathrm{MJ} / \mathrm{m}^{2}$

I Photovoltaic cell output current, A

M The total mass of water in the tank, $\mathrm{kg}$

$Q_{w} \quad$ Water flow, $\mathrm{kg} / \mathrm{s}$

$T_{\text {initial }} \quad$ Initial temperature of tank, ${ }^{\circ} \mathrm{C}$

$T_{\text {final }} \quad$ Tank end temperature, ${ }^{\circ} \mathrm{C}$

$U \quad$ Photovoltaic cell output voltage, $\mathrm{V}$

$\varphi \quad$ Collector battery coverage, $\%$

$\eta_{p v / t} \quad$ PV/Tcollector photoelectric efficiency, \%

$\eta_{p v / t c} \quad$ Contrast PV/T collector photoelectric efficiency, \%

$\eta_{p v} \quad$ Ordinary PV photoelectric efficiency, \%

$\eta_{\text {th }} \quad$ PV/T collector efficiency of hot water collection, \%

\section{Acknowledgments}

This research was funded by [National Key Technology R\&D Program] grant number [2017YFC0702600], [National Natural Science Foundation of China] Grant number [51606002], [Project for postdoctoral researchers in Hefei] and "Four ones" innovation main platform project of Anhui Province.

\section{References}

1. A. Dubey Swapnil, Sarvaiya Jatin Narotam,Seshadi Bharath. Temperature dependent photovoltaic (PV) efficiency and its effect on PV production in the worldea review. Energy Procedia 2013;33:311-21.

2. Meneses-Rodriguez David, et al. Photovoltaic solar cells performance at elevated temperatures. Solar Energy 2005;78(2):243-50.

3. Skoplaki Elisa, Palyvos John A. On the temperature dependence of photovoltaic module electrical performance: a review of efficiency/power correlations.Solar Energy 2009;83(5):614-24.

4. Wolf Martin. Performance analyses of combined heating and photovoltaic power systems for residences. Energy Convers 1976;16(1-2):79-90.

5. Raghuraman , P. Analytical Predictions of Liquid and Air Photovoltaic/Thermal, Flat-Plate Collector Performance.80.4(1979):16-21.

6. Bhattarai Sujala, et al. Comparative study of photovoltaic and thermal solar systems with different storage capacities: performance evaluation and economi-c analysis. Energy 2013;61:272-82.

7. He Wei,Zhang Yang,Ji Jie.Comparative experiment study on photovoltaic and thermal solar system under natural circulation of water [J]. Applied Thermal Engineering, 2011, 31(16):3369-3376.

8. Ji Jie,Chow Tin-Tai, He Wei.Dynamic performance ofhybrid photovoltaic/thermal collector wall in Hong Kong $[\mathrm{J}]$. Building and Environment, 2003,38(11) :1327-1334.

9. Guo Chao,Ji Jie,Sun Wei, et al. Experimental investigation of tri-functional photovoltaic/thermal solar Collector $[\mathrm{J}]$. Energy Conversion and Management,2014,88:650-656.

10. Fudholi A, Sopian K, Yazdi M H, et al. Performanceanalysis of photovoltaic thermal (PVT) water collectors $[\mathrm{J}]$. Energy Conversion and Management, 2014, 78 (2) :641-651.

11. Ma Jinwei, Sun Wei, Ji Jie, et al. Experimental and theoretical study of the effificiency of a dualfunction solar collector. Applied Thermal Engineering 2011,31, 1751-1756. 